\title{
Irregular maritime migrations: islands in the network of routes
}

Dirk Godenau and Daniel Buraschi

The Canary Islands are part of the irregular maritime routes for African emigration to the European mainland. The small size of the islands, in geographic, demographic and economic terms, poses a unique challenge to managing the arrival of migrants, specifically if we consider the relative unpredictability of the phenomenon. This makes it necessary to consider certain key elements in order to understand how irregular maritime migrations toward the Canary Islands have evolved in the past decade.

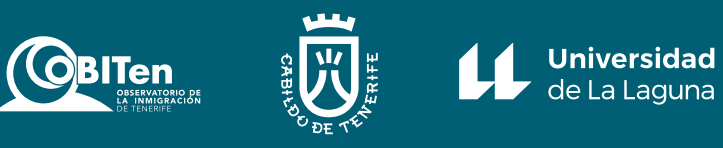




\section{Islands in the network of routes}

Given that oceans cover four-fifths of the Earth's surface, it should come as no surprise that, prior to the development of aviation, people's mobility between continents was closely related to maritime transport and relied on a network of islands that provided logistical support bases for these routes and channelled international migrations. Today, even though much of the intercontinental mobility of people involves air travel, islands continue to occupy a special place in the literature on international migrations, particularly in the field of irregular maritime migration.

Why do people lacking the visas required for regular migration opt for irregular maritime voyages? There are various reasons for this. Boarding a scheduled flight entails checking the passengers' identity. The airspace is supervised by an extensive technological network, which makes the cost of irregular air travel unaffordable. In turn, the cost-benefit ratio for the irregular maritime option involves other factors such as the assessment of alternate land routes, the distances and the risks inherent to the marine environment, the chances of boarding on the coast of departure without being intercepted and the probability of detection and subsequent diversion at the coast of destination.

It is in this context that islands take on a unique interstitial position, since their location, between continents, shortens distances and, if the islands belong to the country of destination (islands of the European Union, for example), reaching one of them could mean that the migrant has finally succeeded in crossing the border, and could potentially be transferred to the mainland. Australia's immigration policy is an example of the exceptions to this rule, since some of the islands in its national territory are excluded for immigration purposes. No such exception exists for the islands that belong to the European Union.

There are hundreds of European islands, but only some are of significance to migration routes and, by extension, have received the attention of the media. Lampedusa, Lesbos, Malta and the Canary Islands are notable examples of insular cross-border areas that are also part of various migration routes. Their importance waxes and wanes over time as migration routes evolve, as does the prominence of the islands in the group of irregular migration routes as a whole.

The analyses done of the irregular immigration on these islands underscore how the small size of these spaces in geographic, demographic and economic terms pose a challenge to sheltering the migrants, especially if the arrivals swing unpredictably over time and there is no permanent infrastructure in place to handle them. Moreover, in contrast to mainland settings, the irregular geographic nature that characterises islands means that migrants, when leaving the island, will be less likely to go unnoticed, due to the greater monitoring of aerial and maritime routes. Finally, islands demand a considerable expansion in terms of the area under surveillance for border control purposes, as compared to an uninterrupted mainland border. 


\section{The Mediterranean and Atlantic migration routes}

The statistics published in the annual and quarterly FRONTEX reports on detections of irregular crossings of the European Union's external borders differentiate between eight routes (see Map 1), whose characteristics result from a combination of their land or maritime nature and their geographic location (eastern, central, western). The two routes involved in the arrival of irregular maritime migrants to Spain are the western Mediterranean and the Atlantic (western African) routes.

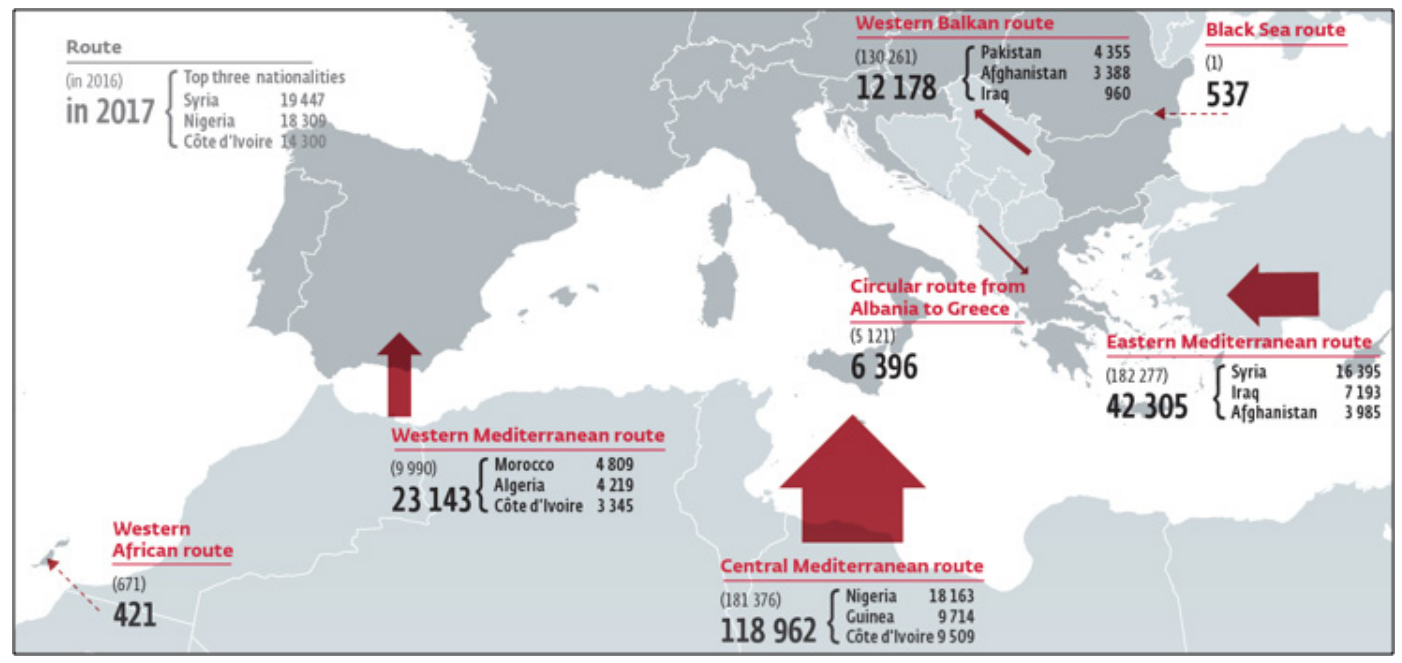

The recent trends in the use of these routes is summarised in the following general pattern (see Table 1):

- The years 2015 and 2016 saw exceptionally high numbers due to the sudden spike in arrivals via the western Mediterranean and the western Balkans routes, while the figures for 2017 reflect a quick return to levels from before the "refugee crisis."

- Related to the above is the temporary downtrend in the use of the western Mediterranean and Atlantic routes (0.4\% of all detections in 2015), before suddenly rising to an $11.3 \%$ share in 2017 (23,143 detections) for the western Mediterranean route and $0.2 \%$ in the Atlantic route (421 people). Despite this recent change, the remaining Mediterranean routes still exhibit much higher numbers, accounting for nearly $80 \%$ of all detections.

- Of the irregular maritime migrants who reach Spain, the Atlantic route via the Canary Islands held a residual place of $1.8 \%$. This situation is far removed from that experienced in 2005 to 2007 (Graph 1), when the Atlantic route was temporarily the main course for arrivals. Moreover, the 874 detections along this route in 2015 were more than double those recorded in 2017 (421). It is during 2018 that there has been a notable increase, with 1,215 detections through the end of October, meaning that by the end of 2018, these arrivals will have exceeded the figures recorded in 2015 .

- Currently, the maritime routes greatly exceed the journeys via land routes in terms of detections at the external borders of the European Union. Once the Balkans land route was "closed", 86.1\% of the detections in 2017 were associated with maritime routes. As stated in Frontex (2018, p. 8), "Looking ahead, irregular migration by sea, and more specifically along the Mediterranean routes, will remain the main modus operandi for illegally crossing the EU's external borders."
Map 1

Irregular crossings detected at the external borders of the EU (2017).

Source

Frontex Risk Analysis for 2018, p. 8. 


\begin{tabular}{|c|c|c|c|c|c|c|c|}
\hline \multirow{3}{*}{$\begin{array}{r}\text { Table } 1 \\
\text { Irregular crossings } \\
\text { detected at the external } \\
\text { borders of the European }\end{array}$} & \\
\hline & Route & 2014 & 2015 & 2016 & 2017 & $\begin{array}{l}\% \text { of } \\
\text { total } \\
2017\end{array}$ & $\begin{array}{l}\text { \% growth over } \\
\text { previous year }\end{array}$ \\
\hline & Central Mediterranean & 170.664 & 153.946 & 181.376 & 118.962 & 58,0 & -34 \\
\hline & Eastern Mediterranean & 50.834 & 885.386 & 182.277 & 42.305 & 21,0 & -77 \\
\hline Source & Maritime & $z$ & 873.179 & 174.605 & 34.732 & 82,0 & -80 \\
\hline Frontex Risk Analysis & Land & 6.777 & 12.207 & 7.672 & 7.573 & 18,0 & $-1,3$ \\
\hline & $\begin{array}{l}\text { Western } \\
\text { Mediterranean }\end{array}$ & 7.243 & 7.004 & 9.990 & 23.143 & 11,0 & 132 \\
\hline & Maritime & 4.749 & 5.740 & 8.641 & 21.632 & 93,0 & 150 \\
\hline & Land & 2.494 & 1.264 & 1.349 & 1.511 & 6,5 & 12 \\
\hline & Western Balkans & 43.357 & 764.038 & 130.261 & 12.178 & 5,9 & -91 \\
\hline & $\begin{array}{l}\text { Circular route from } \\
\text { Albania to Greece }\end{array}$ & 8.841 & 8.932 & 5.121 & 6.396 & 3,1 & 25 \\
\hline & Eastern borders & 1.275 & 1.927 & 1.349 & 776 & 0,4 & -42 \\
\hline & Black Sea & 433 & 68 & 1 & 537 & 0,3 & 53600 \\
\hline & Western Africa & 276 & 874 & 671 & 421 & 0,2 & -37 \\
\hline & Other & 10 & 2 & 1 & 1 & 0,0 & 0 \\
\hline & Total & & 1.822.177 & & & 100 & 100 \\
\hline
\end{tabular}

The changes observed along the routes are the result of a complex web of factors, including the emigration pressures generated by structural and financial forces in the countries of origin; the passability and risks of the routes used prior to reaching the coasts from which the vessels depart; and the relative impermeability of the maritime routes (probability of interception before leaving, risks and costs of the sea journey, arrival and shelter conditions, probability of subsequent transfer to the desired final destination). This set of probabilities affecting the crossing depends not only on the restrictive actions along each of the routes (migratory controls), but must also consider the (re)permeabilisation by the facilitators. The opening of alternate routes, the introduction of technological changes (means of transport, communications, counter-surveillance) and arranging for selective and temporary opacities at the borders are among the functions performed by these facilitators.

In this regard, and despite its frequent mention in the media and even in academic circles, the explanation for the evolving routes should not rely on physical metaphors such as "water finds a way" or "if you press on one side of a balloon, it expands to the other side". These metaphors are not able to capture the social process that comprises borders: the routes are built and managed through the interaction between facilitating and restrictive forces. On the side of migration control there is a multi-layered migratory deterrence that starts with surveillance of the border itself and continues inward (internal controls). In this sense, sealing the borders entails much more than fences and walls. These physical obstacles tend not to be either the most effective or efficient deterrents, except to showcase a supposed political iron will in the face of public opinion. 


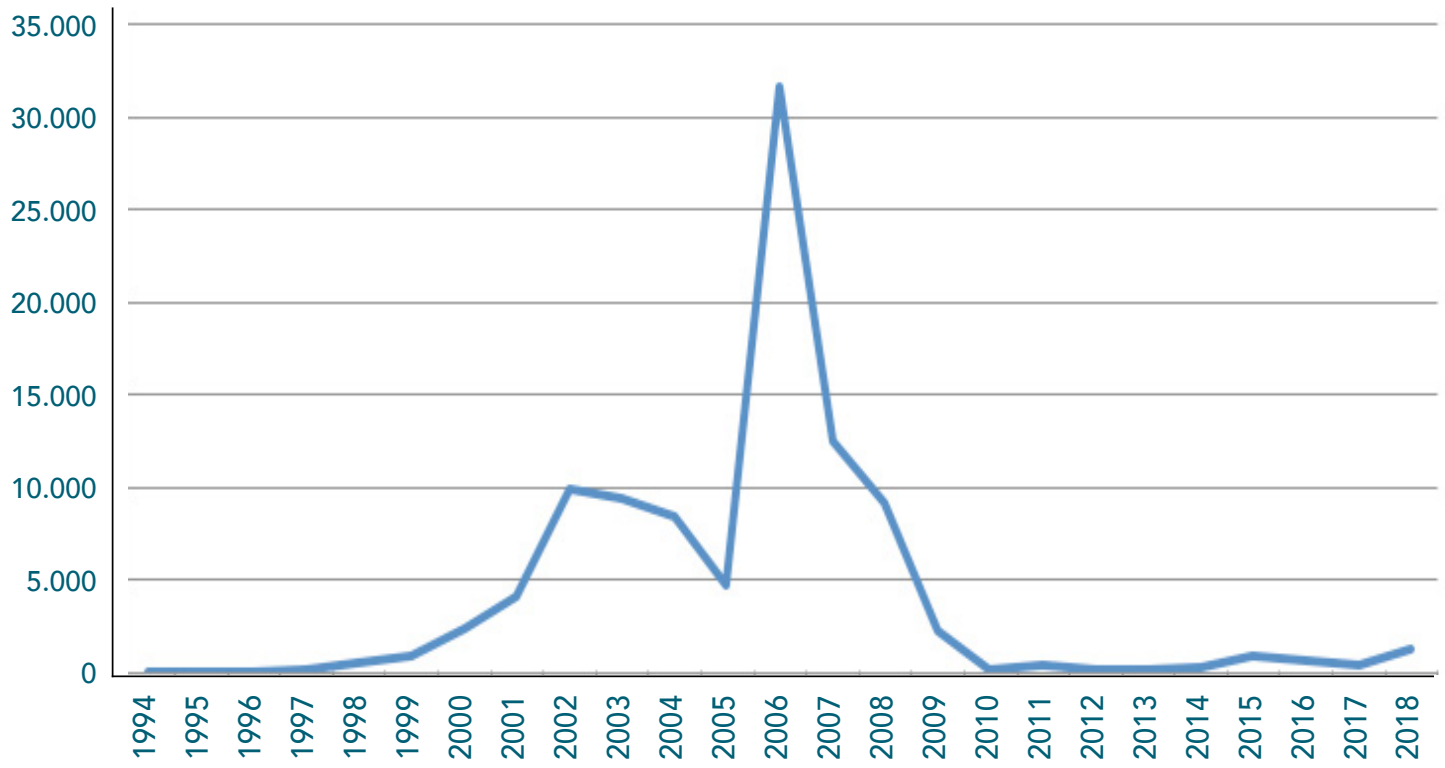

\section{Borders, the media and public opinion}

Borders cannot be viewed as fixed limits, but rather as social constructs that reflect power relationships and that are subject to a process of constant creation. Borders, their social significance and efficacy, are built and rebuilt through the actions of political institutions, the media and civil society. Understanding the dynamics of borders requires recognising their symbolic function, as well as how the media and public opinion contribute to enhancing borders, to their resignification or to their opposition.

In general, civil society experiences borders primarily through the media, in the sense that most people have a view of borders that is conditioned by the media. If part of our knowledge depends on the media, the social agenda will be strongly conditioned by the media's agenda, with the most notable components of the media's agenda becoming equally notable components of public opinion. The media is able to shift the public's interest to specific questions, and is equally able to exclude certain events. Irregular maritime migration, for example, despite not being the primary method of entry for irregular immigrants, is one of the recurring themes in the media when talking about migratory phenomena. This practice inflates the effect that the intensity, volume and impact of irregular maritime migrations have on public opinion. It also ignores other aspects related to migrations, like the life experiences of the migrants, their contributions to society and the actions of civil society.

\section{Graph 1}

Persons detained arriving at unauthorised points of the Canary Islands on board vessels between 1994 and 2018.

Note: provisional 2018 data through the end of October.

\section{Source}

Ministry of Interior and specialised press. 
Table 2

Distribution of news articles published in 2016 and 2017 relating to the migratory phenomenon in the Canary Islands (EI Día, Diario de Avisos, La Opinión and Canarias 7).
Box 1. How irregular maritime migrations are represented in local newspapers in Tenerife

As concerns migration, an analysis of the headlines published in some of the main newspapers in the Canary Islands (El Día, Diario de Avisos, La Opinión and Canarias 7) reveals the clear predominance of subjects related to maritime borders and the irregular entry of migrants. It should be noted that, in general, immigration has not been a particularly relevant topic of the media's agenda in the Canary Islands. Over the course of 24 months, the four newspapers analysed published 368 articles involving the migratory phenomenon, of which 192 were directly related to migrations affecting the Canary Islands.

\begin{tabular}{l|c}
\hline Articles & $\%$ \\
\hline Access to services (healthcare, education, welfare, etc.) & 3,6 \\
\hline Charity activities to aid immigrants and refugees & 1,0 \\
\hline Sheltering of refugees and minors & 4,7 \\
\hline Enrolment of foreigners in social security & 11,5 \\
\hline Analysis of the migratory phenomenon & 4,2 \\
\hline Foreigner Detention Centres & 5,2 \\
\hline Violations of immigrants' rights & 5,2 \\
\hline Emigration of Canary Islanders & 3,6 \\
\hline Life experience of migrants & 0,5 \\
\hline Maritime borders and irregular crossings & 48,0 \\
\hline Migration policy & 5,2 \\
\hline Nationalisation process & 2,6 \\
\hline Social projects related to sheltering and integrating immigrants & 3,1 \\
\hline Victims of sexual exploitation & 1,6 \\
\hline
\end{tabular}

Between 2016 and 2017, $48 \%$ of the news articles were related to the maritime border and the irregular entry of immigrants. This focus includes news on the arrival of small boats, the arrest of boat captains, the rescue of immigrants by marine rescue units and the death of immigrants as they attempted to reach the islands by sea. One particularly important aspect to understanding the prototypical image that residents of the Canary Islands may have of immigrants is that if we focus on the groups of immigrants that are portrayed in the news, immigrants in an irregular administrative status are mentioned in two-thirds of the news reports. These figures show how irregular maritime migrations in 2016 and 2017, despite representing a numerically insignificant phenomenon, are at the centre of the media agenda when speaking about migrations in the Canary Islands. 


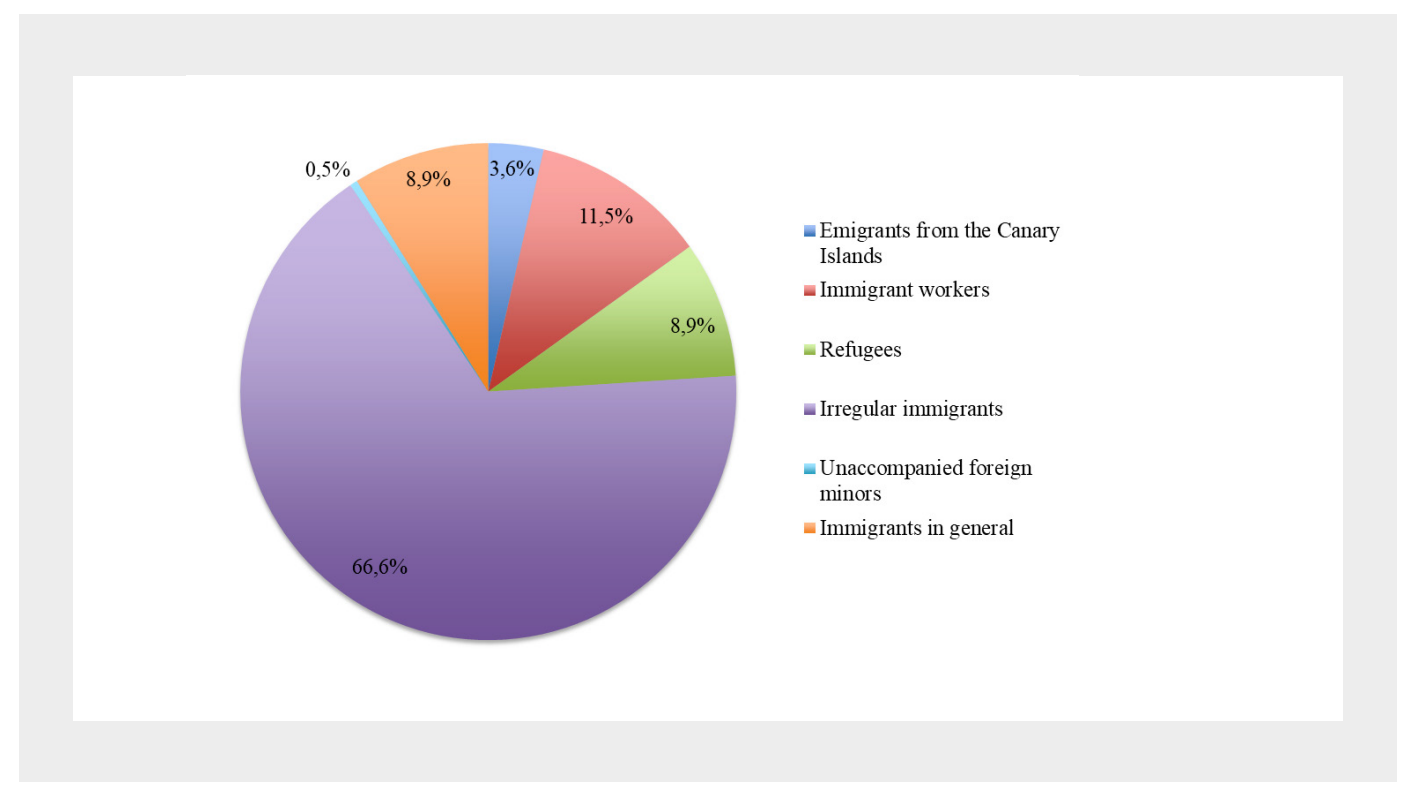

Graph 2

Distribution of the groups that are covered by the news articles published about migrations in the Canary Islands.

In addition to defining the relevant issues, the media always, explicitly or implicitly, frames the news, as a result of which it channels certain values, beliefs and expectations that influence the target audience. Framing the news means approaching a subject in a specific way, assigning certain characteristics, selecting the key expressions that shape the discourse, placing emphasis on some of these expressions, and defining a central idea around which to present the information.

Simplifying, we could say that in Spain, as in all other European countries, there are two dominant frames when reporting on borders and irregular maritime migrations, a "security approach" and a "humanitarian approach". The security approach focuses on the danger posed by irregular migrations, with the migrants being represented as a threat and underscoring the need to protect oneself in the face of immigrant arrivals. The humanitarian approach portrays migrants as victims to be rescued, or at least worthy of compassion. These approaches can have a significant impact on public opinion. In the first case, it can generate social unrest, with citizens calling for reinforced borders and stricter controls. In the second case, public opinion could require a change in migration policy, government intervention in rescue efforts and its involvement in solidarity actions.

There is a circular relationship that exists between the media, political discourse and public opinion. On the one hand, the political discourse and media can influence public opinion; on the other, public opinion, especially in a context where social media and the online discourse in general have a significant bearing on our daily communications, can have an important impact on the media, and on the political discourse and activities. In recent years, for example, various tragic events involving irregular maritime migration have had an enormous effect on society, which in turn triggered an important, though fleeting, political impact on border management. On 3 October 2013, for example, the shipwreck and death of 360 people off the island of Lampedusa created social pressure that forced the Italian government to implement a considerable search and rescue operation called "Mare Nostrum", which remained in effect for a year and transformed the maritime border near Lampedusa from a "strictly secure" space where control actions were prioritised, into a "humanitarian space" where migrant rescues were emphasised. 
However, the most paradigmatic case for the influence of public opinion on the process of constructing and deconstructing borders was the photograph of Aylan Kurdi, a Syrian boy who drowned and was found on a Turkish shore on 2 September 2015. The next day, his image went viral, transforming into a phenomenon that was able to define and summarise the "refugee crisis". The images of Aylan created a wave of indignation and solidarity in civil society, and in the days that followed, political officials changed their discourse on border management and the refugee crisis. In the wake of the emotional wave triggered by that photo, numerous social movements and initiatives in favour of refugees emerged, such as the Bienvenidos Refugiados, Candelaria Ciudad Refugio and Acogida Comunitaria platforms in Tenerife. The case of Aylan Kurdi showed the ability of social media to create alternative narratives to the institutional discourse on migration and borders. The image of Aylan has been reused, repurposed and creatively interpreted in hundreds of campaigns, initiatives, performances, sketches and memes that denounced Europe's inability to react to the refugee crisis.

While these examples show how social movements, NGOs and citizens at large can play a very important role in redefining a border space to make it more "humanitarian", there are also numerous examples of the presence of a vicious circle between the discourse in the media, the xenophobic political discourse and public opinion that turn walls and fences into symbols of the separation between "us" and "them", such as the political rhetoric surrounding the strengthening of the wall that separates the United States and Mexico. In this case, the purpose of numerous walls, fences and razor wire is often not merely to hamper the entry of undesired persons, but to materialise and spectacularise moral borders. Walls and razor wire become an instrument of political propaganda. Moreover, society's indifferent or hostile attitudes toward certain groups of immigrants may legitimise, normalise and justify violence at the borders and the systematic violation of human rights, such as summary expulsions, refusal to provide aid, racial profiling, etc.

In this case, physical border control areas, public opinion and the media are interacting to create a "border spectacle", in which "illegality" is made dramatically and spectacularly visible. The media coverage of border controls, describing the arrival of irregular immigrants as an "invasion", a "dangerous mob", helps reinforce not only physical borders, but symbolic ones that exclude immigrants in an irregular administrative status from the community of people who have rights. 


\section{Box 2. The pull effect: scope and limitations of the concept}

The "pull effect" usually comes up in political and media discussions when trying to criticise a migratory policy that is deemed to be insufficiently restrictive, either due to the permissivity of controls at the border or to the possibilities that are offered to irregular immigrants to regularise their status. The argument is that these accommodations attract other people who, under less favourable conditions, would not select Spain as the destination of their migratory plans.

The purpose served by the "pull effect" talking point is that it makes it possible for the user of the talking point to avoid having to explicitly state his support for actions that make the destination less appealing, and how migratory deterrence prolongs the irregular status (and labour exploitation), and possible support for a "flexible" interpretation involving rights (summary expulsions, shifting borders).

There is no question that migrants, when deciding on a potential destination for their journey, take into account the living conditions they expect to encounter. Therefore, worsening said conditions could provide a deterrent (difficult to quantify). But there is a price to pay for worsening the way immigrants are treated: the constant threat of deportation, driving the underground economy with people devoid of labour rights and the anguish created for those who are affected are among the collateral effects of a "no country for immigrants" type of deterrence. To say nothing of the shadow it casts on the self-image of a society that prides itself on respecting everyone's basic rights.

\section{Conclusion}

The Canary Islands are part of the African emigration routes to the European continent. Following a temporary surge in the use of this route from 2005 to 2007, in 2017 it accounted for just $0.2 \%$ of all arrivals on the European continent, though it ticked up in 2018. European islands provide arrival points at the European Union's external borders, and their changing prevalence in transit migrations in this network of routes depends on the relative permeability of said borders. Migration control actions at the destination, origin and transit points, the variable sources of geopolitical instability and changing land routes on the African continent condition this (im)permeability.

In discussions on immigration, the media's coverage of arrivals by boat shines a light on this method that is disproportionate to its importance in migratory flows. This exaggerated coverage is generally manifested through two types of media framing: security and humanitarian. Both trigger emotional reactions in public opinion. The former causes feelings of insecurity and fear, and the second of empathy and solidarity. It is within this ambiguity that European society's relationship with its border lies. 
For more information:

FRONTEX (2018), Risk Analysis for 2018, Warsaw. [www.frontex.europa.eu]

Godenau, D. \& Zapata Hernández, V.M. (2008), "The Case of the Canary Islands (Spain): A Region of Transit between Africa and Europe", in Pinyol, G. (ed.), Immigration flows and the management of the EU's southern maritime borders, Editor CIDOB, Barcelona.

López-Sala, A. \& Godenau, D. (eds.) (2018), Estados de contención, estados de detención. El control de la inmigración irregular en España, Anthropos Editorial, Barcelona.

\section{How to cite this article:}

Godenau, D. \& Buraschi, D. (2018). Irregular maritime migrations: islands in the network of routes. OBITen Factsheet 2-2018. Retrieved from www.obiten.net.

The Tenerife Immigration Observatory is a joint initiative of the Tenerife Council and the University of La Laguna that is intended to provide a permanent and dynamic structure to advance our scientific knowledge of migratory movements. The OBITen carries out its activity by gathering, producing and disseminating knowledge to facilitate qualified opinions and promote the making of decisions that help to better manage migratory phenomena and their implications.

\section{http://www.obiten.net}

